\title{
Struktur Sosial Politik Kerajaan Loloda di Antara Minoritas Islam dan Mayoritas Kristen Abad XVII-XX
}

\author{
Abd. Rahman ${ }^{1}$
}

\begin{abstract}
Abstrak
Loloda adalah sebuah kata atau konsep yang terkait dengan suatu tempat, bahasa, etnik, mitologi, masyarakat, kerajaan, dan agama, dengan sejarah panjang yang masih kabur. Loloda secara bahasa adalah bahasa orang-orang Loloda, etnik adalah suku bangsa Loloda, mitologi adalah mitos asal mula keberadaan orang dan raja-raja yang pernah menjdi penguasa tertinggi di kerajaan Loloda yang tidak terlepas dari tradisi-tradisi lokal masyarakatnya. Loloda adalah suatu komunitas masyarakat yang telah sejak berabad-berabad yang lalu mendiami sebuah wilayah geografis yang luas. Loloda adalah salah satu kerajaan yang berada di kawasan Laut dan Kepulauan Maluku bagian utara yang cenderung belum dikenalLoloda dan Moro, oleh kebanyakan ahli dianggap adalah dua kerajaan yang sejauh ini belum diketahui kapan terbentuknya. Namun untuk Loloda sendiri menurut beberapa tradisi lokal mengatakan bahwa secara politis kerajaan ini sudah ada sejak tahun 1220 (abad ke-13), sedangkan Moloku Kie Rahayang terbentuk berdasarkan perjanjian Moti/Traktat Moti dan terkonfigurasi pula ke dalam Motir Staten Verbond13221343, secara bersamaan baru muncul pada 1320-an (abad ke-14).Sejak abad ke$15(1486)$
\end{abstract}

Kata Kunci: Loloda, Struktur, Sosial, Agama, Sejarah

\begin{abstract}
Loloda is a word or concept associated with a place, language, ethnic, mythology, society, empire, and religion, with a long history that is still vague. Loloda in the language is the language of the people Loloda, ethnic tribes are Loloda, mythology is the mythical origin of the existence of people and the kings that ever menjdi highest ruler in the kingdom Loloda which is inseparable from the traditions of local communities. Loloda is a community of people who have since many centuries ago inhabited a vast geographical area. Loloda is one of the kingdom which is in the Mediterranean region and northern Maluku Islands which tend not dikenalLoloda and Moro, by most experts consider these two kingdoms which so far is not yet known when the formation. But for Loloda itself according to some local traditions say that politically this kingdom has existed since 1220 (the 13th century), while Kie Rahayang Moloku formed by Moti agreement / treaty Moti and configured into the inner Motir Staten Verbond1322-1343, simultaneously emerged in the late 1320s (the 14th century) .Since the 15th century (1486)
\end{abstract}

Keywords: Loloda, Structure, Social, Religion, History

\footnotetext{
${ }^{1}$ Studi Ilmu Sejarah-Fakultas Sastra dan Budaya Universitas Khairun Ternate \& Departemen Sejarah Fakultas Ilmu Pengetahuan Budaya Universitas Indonesia.
} 


\section{Pendahuluan}

Fokus kajian di dalam artikel ini adalah Loloda dalam konteks sejarah perkembangan kehidupan beragama yang dalam hal ini terfokus pada agama Islam dan Kristen, sebagai bagian dari kehidupan sosial budaya masyarakat daerah ini. Loloda sebagai sebuah kerajaan tua di kepulauan rempahrempah di kawasan laut dan kepulauan Maluku ini menarik untuk dipertanyakan apakah kerajaan ini kerajaan Islam (kesultanan) atau bukan? Apakah status Loloda justru adalah kerajaan Kristen, karena masyarakatnya secara umum justru didominasi oleh penduduk beragama Kristen yang tersebar di banyak kampung dan desa-desanya baik di utara maupun di selatan, yang pada sisi yang lain struktur pemerintahan kerajaannya bernuansa Islam, karena para raja dan bangsawannya justru sejak abad ke-17 hingga sekarang adalah orang-orang beragama Islam? Fenomena ini sangat jauh berbeda dibanding Ternate, Tidore, Bacan, dan Jailolo yang sudah dikenal sebagai kerajaan-kerajaan Islam dengan rajanya-rajanya yang bergelar Sultan.

Loloda adalah sebuah kata, konsep, dan istilah yang identik dengan suku bangsa (etnik), bahasa, kerajaan, sejarah, geografi, budaya (adat-tradisi), mitologi, dan persaingan yang terjadi dalam hal agamisasi, yang dalam hal ini adalah antara Islam yang disebarkan terutama oleh para mubaligh baik dari TimurTengah (Arab) maupun India (Gujarat), serta Jawa dan Melayu, dengan agama Kristen yang disebarkan oleh para misionaris dan orientalis asing Eropa yang masuk melalui bangsa-bangsa Barat (Portugis dan Spanyol dengan Kristen Katolik-Roma dan Katolik Ortodoksnya) dan Belanda dengan agama Kristen Protestannya) melalui misi dan zendingnya (UZV), termasuk yang terjadi di Maluku Utara. Islam tersebar melalui jalur-jalur pelayaran dan perdagangan baik melalui darat (jalur sutra) maupun melalui laut. Teori Balapan agamisasi antara islamisasi dan kristenisasi memang telah terjadi sejauh pembacaan sumber-sumber sejarah sebelumnya (Saifuddin Zuhri mengenai teori-teori Islamisasi di Indonesia dan lihat pula teori $3 \mathrm{G}$ yang terkait dengan konsep dasar, sasaran, dan tujuan kedatangan bangsa-bangsa Barat di Nusantara, sejak abad ke-16 hingga 19).

Loloda sesungguhnya memiliki sejarah panjang sebagai bagian dari sejarah kawasan laut dan kepulauan Maluku. Kerajaan initermasuk tidak dikenal oleh banyak orang.Informasi sejarah mengenai Loloda dalam segala dimensi kehidupannya belum pernah ditemukan. Kalaupun ada maka masih bersifat umum dan tidak mendalam. Loloda adalah sebuah wilayah geografis yang sejak abad ke-13 hingga kini dikenal oleh masyarakatnya sebagai bekas kerajaan pertama, tertua, dan terbesar di kawasan laut dan kepulauan Maluku bagian utara. Sejumlah penulis lokal maupun asing juga pernah menyebutkan julukan-julukan Loloda itu sebagaimana yang dikenal oleh masyarakatnya tersebut. Namun para penulis itu tidak pernah mengungkapkan ini secara lebih mendalam latar belakang dan cikal bakal kerajaan ini. Tidak ada pula penjelasan mengenai mengapa kerajaan Loloda adalah yang terbesar di antara kerajaan-kerajaan lain di sekitarnya. Tetapi dalam beberapa sumber asing dan lokal yang keberadaannya sudah sangat langka mengatakan bahwa setelah abad ke-17 kerajaan ini sudah hilang sehingga sudah sangat jarang disebut-sebut dalam banyak referensi sejarah mereka.

Loloda adalah salah satu wilayah yang menjadi bagian dari kepulauan rempah-rempah (the spices islands) iniyang dalam banyak referensi tesebar 
dan terpisah-pisah serta langkah itu nampaknya kurang banyak diketahui orang, dibandingkan dengan empat kerajaan utama lainnya di kawasan ini yaitu: Ternate, Tidore, Bacan (Makian), dan Jailolo (Moti). Menurut letak geografisnya kini, Loloda berada di Pulau Halmahera di bagian utara dan Barat. Loloda secara umum terbagi atas dua bagian yaitu Loloda Utara di Halmahera Utara (Halut) dan Loloda Selatan di Halmahera Barat (Halbar). Halmahera adalah pulau terbesar di Propinsi Maluku Utara. Wilayah dan penduduk Loloda secara administratif berada dan tersebar di Kabupaten Halut dan Kabupaten Halbar. Tipologi geografis Loloda terdiri dari Loloda Daratan, Loloda Kepulauan, Loloda Teluk, dan Loloda Pegunungan.

Banyak ungkapan yang kemudian muncul mengenai Loloda sejauh ini di mana Loloda diindikasikan sebagai kata atau konsep yang terabaikan, tersingkirkan, hilang, dan terlupakan dalam sejarah Lokal Maluku Utara dan sejarah nasional Indonesia. Karya-karya tulis mengenai perjalanan sejarah Loloda sejauh ini masih sangat sulit ditemukan oleh karena itu Loloda tidak banyak diketahui dan karenanya jarang disebutkan. Loloda secara mitologis dan secara geohistoris adalah bagian dari kehadiran atau kemunculan raja dan kerajaan-kerajaan awal dunia Maluku dan Loloda memiliki luas wilayah yang mencakup hampir separuh Halmahera bahkan bisa dikatakan seluruh pulau ini dahulunya adalah bagian dari miliknya. Semestinya ini adalah kebenaran yang tidak dapat diingkari. Akan tetapi rupanya sejarah tentang itu sejauh ini justru masih sangat sulit ditemukan, dan para sejarawan lokal, nasional, bahkan asingpun seolah merasa enggan untuk menulis sejarah Loloda yang mencakup mengenai seberapa luas wilayah Halmahera yang pernah dikuasai Loloda.
Kalaupun ada yang menuliskannya, maka semuanya masih nampak belum mendalam dan rinci. Namun kenyataan, tidak berarti bahwa Loloda telah hilang sama sekali dan bukan berarti bahwa sejarahnya sudah tidak bisa diluruskan atau ditulis kembali, karena sesungguhnya apabila ingin ditelusuri secara lebih jauh maka sumber-sumber yang menyebutkan tentang keberadaan Loloda itu masih bisa ditemukan hanya saja diperlukan ketekunan dan kesabaran mencarinya.

Sesungguhnya masih terdapat sejumlah data tentang Loloda walaupun terhitung langka dalam ketersediannya. Ketersediaan sumber-sumber tradisi lisan nampaknya sejauh ini menjadi sangat penting terutama ketika menghadapi permasalahan kelangkaan sumber-sumber tertulis berupa arsip dan dokumen-dokumen tertulis lainnya dan tentu saja sumber itu dapat menjadi petunjuk awal bagi penemuan sumbersumber sejarah Loloda yang tertulis (Jan Vansina). Oleh karena itu tidaklah etis jika kemudian semangat untuk meneliti dan menulis sejarah kehadiran Loloda menjadi surut, karena sesungguhnya jika bertekun dan bersabar diri maka bisa diyakinkan bahwa sumber-sumber yang dibutuhkan untuk itu masih dapat ditemukan, baik yang bertema sosial, ekonomis, budaya, maupun politik.

Pertanyaan berikutnya yang menarik adalah apakah teori-terori Islamisasi yang selama ini dikenal dan diterapkan di Nusantara, juga berlaku di kerajaan Loloda hingga abad ke-19 itu? Meskipun di banyak sumber yang dikemukakan oleh sejarawan asing itu setelah abad ke-17 menganggap bahwa Loloda hanyalah sebuah kerajaan kecil dan miskin yang sudah hilang tenggelam dari dunia Maluku (Leonard Y. Andaya). Sebuah hipotesis dapat penulis sampaikan di sini bahwa mungkin salah satu yang membuat Loloda tidak 
terkonfigurasi ke dalam Motir Staten Verbond (Persekutuan Raja-Raja Maluku, 1322-1343) di mana Loloda tidak pernah terdengar sebagai kerajaan Islam dengan raja yang bergelar sultan) adalah karena persoalan agama? Karena para peserta pertemuan Moti lainnya menganggap bahwa raja Loloda lemah dan tidak konsisten dalam menyebarkan agama Islam secara luas di kalangan masyarakat-masyarakat primitif pedalaman yang masih didominasi oleh penduduk yang berkepercayaan animisme dan dinamisme atau politeisme, seperti pada etnik Alifuru.

Ketidaktegasan Raja Loloda dalam Islamisasi, membuat rakyat Loloda yang beragama Islam sangat sedikit dibandingkan yang beragama Kristen, mayoritas penduduk Loloda beragama Kristen, karena kelemahan Raja Loloda dalam misi Islamisasi atas penduduk asli Loloda pada hampir semua wilayah kerajaan Loloda hingga kini, justru dimanfaatkan oleh para misionaris Eropa/Barat terutama Belanda dengan Missi dan Zendingnya (UZV) untuk agama Kristen Protestannya. Sehingga empat kerajaan gunung Maluku (MKR) yang sudah resmi menjadi kerajaan Islam sejak abad ke-15 dan yang tergabung ke dalam organisasi Persekutuan Moti, meninggalkan Loloda sendiri dan menolaknya sebagai kerajaan Islam/kesultanan. Gelar Sultan pada raja Loloda tidak diakui dan kerajaan Loloda pun tidak diakui sebagai sebuah kesultanan di Maluku. Hipotesis ini adalah merupakan suatu hal yang aneh namun menarik untuk diuji kebenarannya dan dalam hal ini, kasus Loloda adalah merupakan suatu pengecualian apabila dibandingkan dengan kerajaan-kerajaan yang sudah berbasis Islam di Maluku dengan raja yang bergelar sultan, seperti Kesultanan Ternate, Kesultanan Tidore, Kesultanan Bacan, dan Kesultanan Jailolo.
Keempat kerajaan inilah yang terkonfigurasi ke dalam organisasi Persekutuan Raja-Raja Maluku, dari hasil Pertemuan Moti (di pulau Moti) di abad ke-14 tersebut. Keempatnya kemudian dikenal dengan Moloku Kie Raha (empat kerajaan gunung Maluku).

Sesungguhnya Loloda adalah bagian integral dari Dunia Maluku. Namun, kenyataannya sejarah Loloda seolah hilang dari dunia itu. Adalah menarik untuk meninjau konsep-konsep historiografis dari Bernard Lewis (2009) dalam kaitannya dengan sejarah Loloda yang terabaikan ini yakni, Sejarah yang Diingat, Ditemukan Kembali, dan DitemuCiptakan. Semestinya dari sisi yang lain, Loloda di masa lalu tidak terlepas dari dinamika pergolakan politik di antara kerajaan-kerajaan lokal tradisional dunia Maluku di bagian utara. Nampaknya pertanyaan seperti ini sering muncul di hadapan penulis.

Menjawab pertanyaan ini rupanya tidak semudah apa yang dibayangkan. Perlu kajian mendalam, untuk bisa menjelaskan secara lebih baik setiap jawaban atas setiap pertanyaan yang muncul.

\section{Masuk dan Berkembangnya Dua Agama}

\section{a. Pengaruh Agama Islam dalam Struktur Pemerintahan Kerajaan}

Di Maluku Utara terdapat tradisi lisan tentang masuknya Islam. Dalam tradisi lisan (oral tradition) digambarkan bahwa Islam sudah masuk di kepulauan Maluku terutama Ternate sejak abad kedelapan Masehi atau abad kedua Hijriah. Menurut tradisi ini, pada sekitar abad ke-2 Hijriah (abad kedelapan Masehi), telah tiba empat orang Syekh buron dari Irak di kepulauan Maluku Utara. Mereka adalah Syekh Mansur, Syekh Yakub, Syekh Amin, dan Syekh 
Umar. Kedatangan empat orang Syekh ini dikaitkan dengan terjadinya pergolakan politik di Irak, ketika golongan Syiah dibunuh oleh Penguasa bani Umaiyah dan Bani Abbasyiah. ${ }^{2}$ Syekh Mansyur menyiarkan agama Islam di Ternate dan Halmahera Muka dan ketika tutup usia, ia dimakamkan di gunung Gamalama Ternate. Syekh Yakub menyebarkan agama Islam di Tidore dan Makian, dan ketika tutup usia, ia dimakamkan di gunung Makian (Kie Besi). Syekh Amin dan Umar menyiarkan agama Islam di Halmahera Belakang, Maba, Patani, dan sekitarnya. Keduanya dikabarkan kembali ke Irak. ${ }^{3}$

Kehadiran empat orang Syekh di atas bisa dikatakan melalui Cina yang langsung menuju ke Kawasan Laut dan Kepulauan Maluku bagian Utara (Maluku Utara). Hal ini berdasarkan tiga argumentasi. Pertama, pada masa itu, hubungan Cina dengan Timur Tengah terjadi melalui jalur darat sehingga disebut dengan "jalur sutra". Rempahrempah yang diperdagangkan oleh orang Cina itu diambil dari Kepulauan Maluku. ${ }^{4}$

2 Djoko Suryo, "Bulan Sabit di Bawah Rimbunan Cengkeh: Islamisasi Ternate atau Ternatesasi Islam" dalam Moloku Kie Raha dalam Perspektif Budaya dan Sejarah Masuknya Islam, (Ternate: HPMT Press, 2005), h. 120, dalam Mustafa Mansyur. 2013. Transformasi Politik di Loloda Maluku Utara (1808-1945). (Bandung: PPS-UNPAD (Tesis), 2013), h. 140.

3 Djoko Suryo, "Bulan Sabit di Bawah Rimbunan Cengkeh, h. 120; Irza Arnyta Djafaar, Dari Moloku Kie Raha hingga Negara Federal Biografi Politik Sultan Ternate Iskandar Muhammad Djabir Sjah. (Yokyakarta: Bio Pustaka, 2005), h. 19; dan Mustafa Mansyur, Transformasi Politik di Loloda Maluku Utara (1808-1945), h. 14.

4 R.Z. Leirissa, "Jalur Sutera: Integrasi LautDarat dan Ternate sebagai Bandar di Jalur Sutera" dalam Yusuf Abdulrahman, et al., Ternate Bandar Jalur Sutera, (Ternate: Lintas 2001), h. 4 dalam Mustafa Mansyur. 2013.
Loloda adalah salah satu daerah yang merupakan pusat kekuatan politis yang melahirkan gelar kolano (raja) yang dibantu oleh Jougugu (kapita laut dan hukum), sebagaimana halnya fungsifungsi politik yang serupa di Ternate. Faktanya ialah bahwa penguasa Loloda tertinggi bergelar kolano sebagaimana halnya gelar kolano sebelum digantikan dengan gelar Sultan bagi raja Ternate dan Tidore, namun kemudian Loloda dinyatakan terpisah. Pada abad ke-17 Loloda telah menjadi pusat Islam karena pada tahun $1686^{5}$ namun Islam dinyatakan baru masuk Loloda pada tahun $1656 .{ }^{6}$ Di Loloda desa yang menjadi tempat utama kediaman kolano adalah sebuah desa Muslim di tepi sungai Loloda, yang dapat disimpulkan bahwa kolano pada waktu itu telah menganut Islam juga. Tetapi menurut van Baarda Kolano Loloda dan segenap aparat kerajaannya sudah menganut Islam sebelum abad ke-19 pertengahan. ${ }^{7}$ Jika berpatokan pada pandangan Mapanawang, maka ini berarti bahwa islamisasi di Loloda sungguh sangat lamban jika dibandingkan dengan tempat-tempat lain di Nusantara.

Tahun 1662 penduduk Loloda diperkirakan berjumlah 200 orang dan di tahun 1686 muslim Loloda berjumlah 16 orang. Sementara penduduk Alifuru berjumlah 60 orang.Pada 1911 sekitar 19 desa dengan jumlah penduduk 4000 jiwa

Transformasi Politik di Loloda Maluku Utara (1808-1945), h. 141.

5 Arend L Mapanawang, Loloda Kerajaan Pertama Moluccas (Sejarah Kerajaan Loloda Maluku), (Tobelo: Yayasan Medika Mandiri Halmahera, 2012), h. 63.

6 Arend L Mapanawang, Loloda Kerajaan Pertama Moluccas (Sejarah Kerajaan Loloda Maluku), (Tobelo: Yayasan Medika Mandiri Halmahera, 2012), h. 143.

7 Arend L Mapanawang, Loloda Kerajaan Pertama Moluccas (Sejarah Kerajaan Loloda Maluku), (Tobelo: Yayasan Medika Mandiri Halmahera, 2012), h. 143. 
Muslim, Kristen, dan Pagan. Pada tahun 1686 terdapat lima desa yang ditempati oleh orang-orang Alifuru (di luar desadesa Muslim utama), lima desa orang Alifuru itu adalah Lobo-Lobo, ToboTobo, Kedi Togolami, dan Bakune, mereka semua berjumlah kira-kira 60 orang. Desa-desa Alifuru yang lain adalah, Baru, Bakun, Kedi, dan Laba. ${ }^{8}$ Kedua, jalur pelayaran melalui Selat Malaka belum terjadi, sehingga hubungan antara para pedagang dari Timur Tengah dengan Asia Timur masih melalui jalan darat.

Hubungan melalui jalur laut terjadi ketika Khalifah Abbasiyah mulai mengalami kemunduran pada abad ke10 Masehi. Sejak saat itu, disepanjang Samudra Hindia, baru muncul apa yang disebut "emporium" yaitu kota-kota pelabuhan yang menyediakan segala macam fasilitas bagi kaum pedagang dan pelaut. Jaringan emporium itulah yang memungkinkan pelayaran niaga dari Timur Tengah ke Asia Timur, tidak perlu melalui jalur darat. ${ }^{9}$ Ketiga, kehadiran empat orang Syekh di Kepulauan Maluku Utara ini mungkin lebih awal menyinggahi pesisir UtaraBarat Halmahera, karena secara geografis pesisir Utara Halmahera berada langsung di antara Laut Maluku dan Samudra Pasifik yang menghubungkannya dengan Laut Cina Selatan. Hal ini mengacu pada proses penyebaran Islam yang dilakukan oleh Syekh Mansyur di Ternate dan Halmahera muka. Halmahera muka di

\footnotetext{
8 Arend L Mapanawang, Loloda Kerajaan Pertama Moluccas (Sejarah Kerajaan Loloda Maluku), (Tobelo: Yayasan Medika Mandiri Halmahera, 2012), h. 143.

9 R.Z Leirissa, "Jalur Sutera: Integrasi LautDarat dan Ternate sebagai Bandar di Jalur Sutera" dalam Yusuf Abdulrahman, et al., Ternate Bandar Jalur Sutera, (Ternate: Lintas, 2001), h. 4.
}

sini bisa jadi adalah Loloda dan Ibu. ${ }^{10}$ Berdasarkan tradisi oral yang dikemukakan, dapat dikatakan bahwa Islam telah masuk di Maluku Utara khususnya Ternate dan Loloda sejak abad kedelapan Masehi. Versi lain dapat dilihat dari Hikayat Ternate sebagaimana yang ditulis oleh Naidah dan mitos mengenai kelahiran Raja Loloda.

Di Loloda, meskipun cerita tentang masuknya Islam tidak dimuat dalam berbagai catatan terutama hikayat, namun berdasarkan sumber-sumber lisan, dapat digambarkan bahwa masuknya Islam di Loloda dikaitkan dengan tokoh-tokoh legendaris, yang memiliki kekuatan magis dan supranatural. Mitos kelahiran raja Loloda, ${ }^{11}$ bisa dikatakan bahwa Islam telah masuk Loloda. Hal ini bisa terlihat dari nama Raja Loloda yang menggambarkan nama bercirikan Islam yakni Usman dengan gelar Malamo (agung). Kehadiran empat orang syekh dari Irak di atas, bisa juga dijelaskan bahwa Islam masuk Loloda sejak abad kedelapan Masehi. Hal ini bisa dilihat dari operasi penyiaran Islam yang dilakukan oleh Syekh Mansyur yang meliputi Ternate dan Halmahera muka termasuk Loloda dan Ibu. Meskipun Islam telah masuk di Loloda, namun tidak dapat dijelaskan apakah Islam telah melembaga ke dalam struktur pemerintahan di Kerajaan Loloda pada abad kelimabelas sebagaimana di Ternate. Pada abad ini (1486), Islam telah masuk ke dalam sistem politik di Ternate yang ditandai dengan adanya

10 U.M. Assegaf, "Sedikit tentang Maluku Utara". Buletin IKMU Surabaya. Medio Januari, 1974, h. 15 dalam Mustafa Mansyur, Transformasi Politik di Loloda Maluku Utara (1808-1945). Bandung: PPS-UNPAD (Tesis), 2013), h. 142.

11 Mustafa Mansyur, Transformasi Politik di Loloda Maluku Utara (1808-1945), h. 142. 
gelar Sultan untuk Raja Ternate. Adapun Raja Ternate yang pertama kali memakai gelar sultan adalah Zainal Abidin Sjah. ${ }^{12}$

Di Loloda, Islam dapat dikatakan masuk ke dalam sistem politik setidaktidaknya pada abad ke-17. Hal ini berdasarkan tulisan Chr. F. van Fraassen yang berjudul Types of Socio Political Structure in North-Halmahera History (1979). Menurutnya, pada abad ke-17, Loloda telah menjadi sebuah pusat Muslim karena pada tahun 1686 kampung utama Loloda dan kediaman Kolano Loloda adalah kampung Muslim di tepi Sungai Loloda, sehingga ia menyimpulkan bahwa Kolano Loloda adalah seorang Muslim (Van Fraassen, 1979:115). Namun, Van Fraassen tidak menjelaskan bagaimana posisi Islam dalam sistem politik di Loloda.

Pada abad ke-19, pengaruh Islam di Loloda juga dapat terlihat. Pengaruh itu dapat dilihat dari adanya pemukiman Muslim yakni Soa-Sio dan Bantoli di ibukota Loloda. ${ }^{13}$ Kemungkinan Kampung Muslim yang dimaksud Van Fraassen di atas adalah Soa-Sio, karena Soa-Sio yang dimaksud pada abad ini terletak di tepi Sungai Loloda. Di SoaSio inilah, kediaman atau kedudukan Raja Loloda berada, dan raja juga seorang Muslim. Meskipun raja adalah seorang Muslim, namun dalam sumbersumber Belanda tidak disebutkan eksistensi Penguasa Loloda dengan gelar sultan. Sekalipun demikian dalam pemahaman orang Loloda saat ini, mereka senantiasa memberi konotasi yang sama antara raja (kolano) dengan sultan. Bahkan dalam tulisan Sultan Ternate Mudaffar Sjah tentang "Sejarah

12 Saleh Putuhena, "Struktur Pemerintahan Kesultanan Ternate dan Agama Islam", dalam E.K.M. Masinambow, Halmahera dan Raja Ampat, (Jakarta: Leknas LIPI, 1983), h. 315.

${ }^{13}$ F.S.A. De Clerq, De Bijdragen tot de Kennis der Residentie Ternate. (Leiden: Brill, 1890), h. 74 .
Hukum Adat dan Lingkungan Hidup Adat Ternate", terdapat juga sebutan untuk Sultan Loloda. ${ }^{14}$

Namun untuk mengimbangi kedua pemahaman antara sultan versus kolano, dapat ditelusuri dengan simbol keislaman yang lain yaitu istilah soa-sio yang terdapat pada abad ke-19. Istilah soa-sio ini digambarkan untuk membedakan penduduk yang beragama Islam, di mana istilah Soa-Sio ini digunakan sebagai nama negeri yang berada di pusat-pusat pemerintahan kerajaan dan distrik. ${ }^{15}$ Hal ini sebagaimana yang terdapat di dalam catatan de Clerq 1890, yang menggambarkan adanya negeri-negeri Soa-Sio pada distrik-distrik di Halmahera bagian utara termasuk Loloda.Meskipun de Clerq tidak menjelaskan peran dan fungsi dari negeri-negeri Soa-Sio, namun eksistensi negeri Soa-Sio yang disebut de Clerq memberikan asumsi terdapat pengaruh Islam terhadap sistem politik di Loloda pada abad kesembilanbelas.

Secara etimologis, kata Soa-Sio diambil dari kata 'soa' yang berarti 'rumpun' dan 'sio' yang berarti 'sembilan'. Kata Soa lalu diartikan dengan kesatuan keluarga (marga) dalam suatu masyarakat, dan bisa juga diartikan dalam perspektif alam untuk menunjukkan "teluk". Teluk bisa dimaknai dengan sebutan "jiko", tetapi bisa juga "soa", ketika ada cela-cela yang kosong di antara dua titik di depan dan di belakang. Singkatnya berbentuk

14 Hidayatullah M. Sjah, "Sultan Jailolo; melengkapi Kesempurnaan Moloku Kie Raha" dalam Mudaffar Sjah, et al., Moloku Kie Raha dalam Perspektif Budaya dan Sejarah Masuknya Islam, (Ternate: HPMT Press, 2005), h. 26.

15 R.Z. Leirissa, Halmahera Timur dan Raja Jailolo: Pergolakan Sekitar Laut Seram Awal Abad Ke-19, (Jakarta: Balai Pustaka, 1996), h. 89. 
garis lengkung. Cela-cela itu disebut "soa" atau "ma-soa". 16

Kata soa dalam pengertian marga, kemudian berkembang maknanya menjadi kampung atau negeri. Dengan kata lain, istilah kampung merupakan modifikasi dari kata soa. Istilah kampung sesungguhnya berasal dari bahasa Portugis yaitu "campo". ${ }^{17}$ Selain itu di tengah-tengah masyarakat lokal di Maluku Utara, dikenal pula adanya istilah fanyira yang merujuk pada suatu status dan jabatan sosial sebagai kepala soa. Fanyira dalam bahasa Ternate mengandung makna sebagai orang yang dituakan dalam suatu kampung (soa). Sementara untuk marga (klan), soa-nya bisa merujuk pada suatu sistem kekerabatan berdasarkan asumsi genealogis dan negeri yang biasanya dikategorikan dengan eksistensi atau status wilayah yang dipimpin oleh sangaji, sehingga disebut soa sangaji.

Di Kesultanan Ternate, terdapat juga istilah soa-sio yang digunakan sebagai nama negeri yang menjadi pusat pemerintahan kesultanan. Sebagai pusat pemerintahan, negeri Soa-Sio ini ditempati oleh perwakilan/duta dari golongan masyarakat dari sembilan marga/kampung dan sembilan negeri (sangaji) yang menjadi bagian yang sangat penting di dalamnya. Di dalam konteks inilah, Soa-Sio diartikan sebagai sembilan marga/kampung, dan Sembilan negeri (sangaji) yang kemudian disebut Bobato Delapan Belas (Bobato Nyagimoi Setofkange).

Sembilan marga/kampung tersebut terdiri dari: 1. Kimalaha Marsaoli, 2. Kimalaha Tomagola, 3. Kimalaha Tomaito, 4. Kimelaha Tamadi, 5. Kimelaha Payahe, 6. Fanyira Jiko, 7.

16 Mustafa Mansyur, Transformasi Politik di Loloda Maluku Utara (1808-1945), (Bandung: PPS-UNPAD (Tesis), 2013).

${ }^{17}$ Irza Arnyta Djafaar, Jejak Portogis di Maluku Utara. (Jakarta: Ombak, 2007), h. 151.
Fanyira Jawa, 8. Fanyira Torangara, dan 9. Fanyira Tobala. Para kimalaha di atas merupakan orang-orang (marga) terbaik yang ditunjuk kolano, dan para fanyira adalah utusan dari empat soa (kampung) utama di Ternate. Adapun Sembilan negeri (sangaji) terdiri dari: 1 . Sangaji Tomajiko, 2. Sangaji Malayu, 3. Sangaji Limatahu, 4. Sangaji Kulaba, 5. Sangaji Malayu Cim, 6. Sangaji Tobeleu, 7. Sangaji Tafamutu, 8. Sangaji Tafaga, dan 9. Sangaji Takofi. Bobato ini bertugas sebagai lembaga parlemen kesultanan Ternate. ${ }^{18}$

Sementara dalam bidang eksekutif disebut Bobato Madopolo yang dipimpin oleh Perdana Menteri (jogugu).Menteri yang menangani urusan dalam negeri disebut hukum soa-sio. Hal yang sama juga terdapat di Kesultanan Tidore, di mana istilah soa-sio digunakan sebagai nama negeri yang berkedudukan sebagai pusat pemerintahan Kesultanan Tidore, dan teradapat seorang hukum soa-sio yang menangani urusan dalam negeri. ${ }^{19}$

18 Syahril Muhammad, Kesultanan Ternate Sejarah Sosial Ekonomi \& Politik, (Yokyakarta: Ombak, 2004), h. 49; Talabudin Yusuf. 2005. "Sejarah Kesultanan Ternate" dalam Mudaffar Sjah, et al., Moloku Kie Raha dalam Perspektif Budaya dan Sejarah Masuknya Islam, (Ternate. HPMT Press, 2005), h. 45-46; Busranto Abdul Latif Do'a. "Sistem Kemasyarakatan Tradisional Ternate dalam Perspektif Budaya Modern" dalam Mudaffar Sjah, et. al., Moloku Kie Raha dalam Perspektif Budaya dan Sejarah Masuknya Islam. Ternate: HPMT Press, 2005), h. 98-99; dalam Mustafa Mansyur, Transformasi Politik di Loloda Maluku Utara (1808-1945), h. 146; dan Abd. Rahman Marasabessy, dkk. Sejarah Sosial Kesultanan Ternate. Ombak, 2012), h. 90-91.

19 Hidayatullah M. Sjah, "Sultan Jailolo; melengkapi Kesempurnaan Moloku Kie Raha" dalam Mudaffar Sjah, et al., Moloku Kie Raha dalam Perspektif Budaya dan Sejarah Masuknya Islam, (Ternate: HPMT Press, 2005), h. 35, dalam Mustafa Mansur, Transformasi Politik di Loloda Maluku Utara (1808-1945), h. 146. 
Adapun di Kesultanan Bacan tidak terdapat negeri Soa-Sio.Hanya saja, golongan rakyat jelata (bala) yang telah menganut agama Islam disebut "orang Soa-Sio". Orang Soa-Sio inilah yang dipilih untuk menjalankan pemerintahan seperti pada jabatan jogugu, hukum (hakim) dan kimalaha. $^{20}$ Ini menunjukkan adanya kesamaan dengan istilah soa-sio di Kesultanan Ternate dan Tidore.

Di Jailolo, istilah soa-sio juga disebutkan oleh de Clerq, namun eksistensi soa-sio yang dimaksudkannya itu berkaitan dengan status Jailolo sebagai pusat pemerintahan Distrik Jailolo. Hal ini dikarenakan bahwa pada abad kesembilanbelas tersebut Jailolo bukan lagi sebuah kesultanan melainkan distrik di bawah kesultanan Ternate. ${ }^{21}$

Sementara di Galela, penyebutan istilah soa-sio bisa dikaitkan dengan adanya golongan Muslim yang mendapat satus sosial utama dalam sistem sosial kemasyarakatan, sehingga melahirkan negeri Soa-Sio. Golongan inilah yang kemungkinan menjadi Sangaji/kepala Distrik Galela yang berkedudukan di negeri Soa-Sio. Keadaan ini tergambar dari catatan F.S.A de Clerq yang berjudul "Ternate, The Residensi and its Sultanate," mengungkapkan bahwa di beberapa distrik di Halmahera Utara dan Barat (Jailolo, Sahu, Gamkonora, Loloda, dan Galela) terdapat kampung-kampung soasio yang dihuni golongan Muslim. Keadaan ini menunjukkan bahwa pada pusat-pusat kekuasaan raja (kolano) dan sangaji, sesungguhnya terdapat negeri

\footnotetext{
${ }^{20}$ M. Adnan Amal, Kepulauan Rempah-Rempah Perjalanan Sejarah Maluku Utara 1250-1950. Edisi Revisi. Makssar: Kerja sama Gora Pustaka Indonesia, Nala Cipta Litera, dan Bursa Kawasan Timur Indonesia, 2007), h. 193.

${ }^{21}$ F.S.A. De Clerq, De Bijdragen tot de Kennis der Residentie Ternate, (Leiden: Brill, 1890), h. 70-71.
}

soa-sio.Akan tetapi kampung-kampung Soa-Sio di bekas-bekas distrik tersebut, tidak lagi eksis pada saat ini, kecuali di Ternate, Tidore, Loloda, dan Galela.

Untuk Soa-Sio di Loloda, pengertiannya kurang lebih sama dengan Soa-Sio di Ternate, Tidore, Bacan, dan Galela. Hal ini bisa dilihat dari adanya negeri Soa-Sio yang menjadi pusat pemerintahan kerajaan Loloda (bisa juga disebut distrik). Selain itu, negeri SoaSio juga merupakan pemukiman golongan Muslim. Sebagai pusat pemerintahan kerajaan, di negeri Soa-Sio ini terdapat representasi golongan masyarakat dari Sembilan Soa yang disebut Bobato Soa-Sio. Bobato inilah yang memegang kewenangan/urusan utama dalam sistem sosial politik di Loloda. Sebagaimana telah dikemukakan sebelumnya, ${ }^{22}$ bahwa kewenangan atau urusan dari representasi golongan masyarakat itu di antaranya: 1. Soa Bangsa (golongan bangsawan yang memegang kedudukan raja); 2. Soa Kimalaha (menjalankan pemerintahan), 3.Soa Hukum (melaksanakan peradilan); 4.Soa Lebe (melaksanakan urusan syari'ah Islam); 5. Soa Sabuange (penasehat Kolano); 6. Soa Dumo (pelayan kolano); 7. Soa Kori (penjaga hutan); 8. Soa Tobo-Tobo (penjaga pantai/teluk); dan 9. Soa Mandioli (prajurit perang). ${ }^{23}$

Dengan mengacu pada pengertian Soa-Sio, baik sebagai pemukiman Muslim, pusat pemerintahan, maupun sebagai salah satu soa yang mengurusi masalah syari'ah Islam, maka dapat dikatakan bahwa Islam telah ditransformasikan ke dalam sistem politik Loloda. Hal ini

\footnotetext{
${ }^{22}$ Lihat Mustafa Mansyur, Transformasi Politik di Loloda Maluku Utara (1808-1945), h. 55.

${ }^{23}$ Wawancara dengan Munawar Miraji, pada 25 April 2013 dalam Mustafa Mansyur, Transformasi Politik di Loloda Maluku Utara (1808-1945), lihat, h. 148.
} 
dapat dilihat dari sistem kedudukan raja/kolano (kepala distrik) yang beragama Islam, pusat pemerintahan berkedudukan di negeri Soa-Sio sebagai pemukiman Muslim, dan ada suatu lembaga yang mengurus mengenai masalah Syari'ah Islam dalam Bobato Soa-Sio yakni Soa Lebe. Dalam istilah lokal, lembaga yang menangani masalah Syari'ah Islam disebut Bobato Akhirat. Bobato ini dipimpin oleh seorang imam atau mufti. Dalam istilah lokal, mufti disebut juga dengan $J o$ Qalem atau $J o$ Lebe. $^{24}$

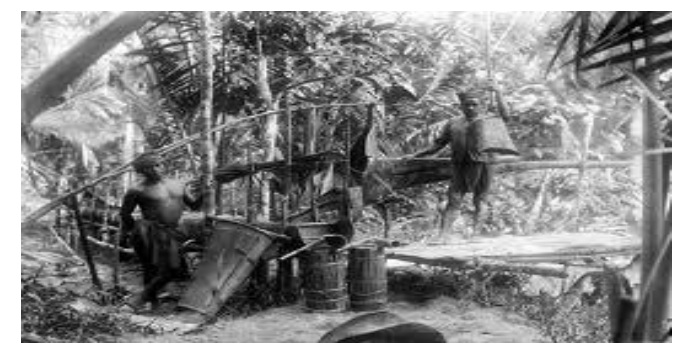

Petani Loloda memanen sagu di Halmahera, Maluku Utara.

COLLECTIE_TROPENMUSEUM_Sagobereidi ng_bij_Loloda_Halmahera_Noord-

Molukken/Nederlands: Negatief. Sagobereiding bij Loloda, Halmahera, NoordMolukken/Tropenmuseum.

Pada awal abad keduapuluh, pengaruh Islam terhadap sistem politik di Loloda juga terlihat, keadaan ini bisa dilihat dari catatan Van Baarda pada 1904 yang berjudul 'Het Loda'sch in Vergelijking met het Galela'sch Dialect op Halmaheira" (perbandingan dialek bahasa Loloda dengan Galalae di

24 Talabudin Yusuf, "Sejarah Kesultanan Ternate" dalam Mudaffar Sjah, et al., Moloku Kie Raha dalam Perspektif Budaya dan Sejarah Masuknya Islam, (Ternate. HPMT Press, 2005), h. 45-46; Abdul Latif Do'a, Busranto, "Sistem Kemasyarakatan Tradisional Ternate dalam Perspektif Budaya Modern" dalam Mudaffar Sjah, et. al., Moloku Kie Raha dalam Perspektif Budaya dan Sejarah Masuknya Islam, (Ternate: HPMT Press, 2005), h. 100 dan Mustafa Mansyur, Transformasi Politik di Loloda Maluku Utara (1808-1945), lihat, h. 148.
Halmahera). Dalam catatan itu, disebutkan bahwa Kolano Loloda adalah seorang Muslim dan di ibukota Loloda dihuni orang Islam, terdapat mesjid dan ada seorang Imam. Selain itu, di sanasini juga ditemukan pedagang yang beragama Islam. $^{25}$ Ini menunjukkan bahwa kedudukan Islam dalam sistem politik di Loloda tetap eksis.

Ketika kedudukan raja (kolano) dilikuidasi dan ditransformasikan dengan kedudukan sangaji oleh Pemerintah Hindia Belanda setelah Februari 1909, pengaruh Islam bisa dikatakan tetap menjadi bagian sistem politik Loloda. Dikatakan demikian karena sangaji yang ditempatkan di Loloda dipastikan seorang Muslim, dan imam atau Jo Lebe tetap berada di bawah sangaji untuk menjalankan syari'ah Islam. Pada perkembangan berikutnya, istilah imam atau Jo Lebe Loloda disebut sebagai imam Distrik Loloda. Adapun Imam Distrik pada saat itu bernama Imam Syawal. ${ }^{26}$

Pengruh Islam terhadap sistem politik di Loloda membawa pengaruh terhadap penyebaran Islam di wilayah Loloda pada masa-masa berikutnya. Hal ini dapat dilihat dari data statistik 1917, terlihat jumlah penduduk Loloda yang telah beragama Islam sebanyak 1155, jumlah itu tersebar di kampung Soa-Sio (248), Tolofuo (330), Baja (56), ToboTobo (87), Fitako (119), Dedeta (149), Dama (103), dan Tate (63). Angka

\footnotetext{
25 M.J. van Baarda. 1904. "Het Loda'sch, in vergelijking met het Galela'sch dialect op Halmaheira". BKI. Vol. 56, No. 1, 1904, hlm. 321. Diakses dari http://www.kitlvjournals.nl/ index.php/btlv/article/viewFile/6762/7529, pada 20 November 2012, pkl. 19.48 WIB.

26 Mustafa Mansyur, Loloda dan Integritas Kesultanan Ternate (1945-1999), (Ternate: Program Studi Ilmu Sejarah-Fakultas Sastra dan Budaya-Universitas Khairun (Skripsi), 2007), h. 65 dan Mustafa Mansyur. 2013. Transformasi Politik di Loloda Maluku Utara, h. 149 .
} 
tersebut termasuk Kampung Pocao, karena dalam data statistik itu, hanya mencantumkan penduduk Pocao terdiri dari Islam dan Alifuru (kafir). ${ }^{27}$

Dengan adanya pengaruh Islam terhadap sistem politik di Loloda, menunjukkan adanya perubahan sosial dalam bidang kebudayaan. Perubahan sosial itu telah mempengaruhi transformasi politik di Loloda, menunjukkan adanya perubahan sosial dan kebudayaan. Perubahan sosial itu telah mempengaruhi transformasi politik di Loloda dari sistem kerajaan ke sistem distrik, namun peran Islam yang dilegitimasikan dalam sistem pemerintahan di Loloda (Bobato SoaSio) yakni Soa Lebe tetap eksis). Dengan demikian dapat dikatakan pengaruh Islam justru merupkan landasan dari sistem politik di Loloda.

Pada masa pendudukan bala tentara Jepang, pengaruh Islam di Loloda dapat dikatakan berjalan di tempat, kalaupun tidak mau dikatakan mati. Keadaan ini dapat dimaklumi karena situasi perang membuat pengaruh Islam dibatasi oleh Jepang. Setelah proklamasi kemerdekaan Indonesia, pengaruh Islam bisa dikatakan ada. Hal ini dapat dilihat dari adanya kedudukan Imam di distrik Loloda saat itu, dan kepala distrik juga adalah Muslim, namun belum bisa dijelaskan bagaimana pengaruh secara lebih jauh.

\section{b. Masuknya Agama Kristen dan Fenomena Mayoritas}

Meskipun data telah ditemukan dalam bentuk silsilah raja-raja dan bangsawan Loloda yang semuanya beragama Islam, namun rupanya penduduk Islam di kerajaan ini justru

\footnotetext{
${ }^{27}$ J.M. Baretta, Halmahera en Morotai Bewerk Naar de Memorie van Den Kapitein van Den Generalen Staf, (Batavia: Javasche Boekhandel \& Drukkerij, 1917), h. 104-106.
}

tidak menjadi dominan. Justru jika dilihat dari komposisi masyarakatnya sejak abad ke-17, nampaknya Islam di Loloda sudah melembaga dan menjadi agama resmi kerajaan, akan tetapi agama warga masyarakat kerajaan ini mayoritas bukanlah Islam, atau bukan mayoritas muslim. Karena hingga kini mayoritas warga masyarakat Loloda di Utara maupun di Selatan dan dalam banyak kampung serta pemukiman penduduk justru lebih banyak yang lebih banyak yang beragama Kristen. Teori Islamisasi secara "top down" (dari atas ke bawah). Yang berarti jika raja telah beragama Islam, apalagi Islam sudah melembaga di dalam struktur pemerintahan kerajaan, maka secara otomatis ajaran Islam pun akan menurun ke rakyat/kawula kerajaan, yang berarti bahwa rakyat/kawula yang kerajaan pun akan memeluk agama Islam dan menjadi Muslim, namun demikian hal ini tidak terjadi di Loloda.

Pada bagian ini sedikit akan disampaikan mengenai kisah kristenisasi yang telah berlangsung di Loloda yang dimulai pada abad ke-19. Meskipun sesungguhnya kedatangan orang-orang Kristen dari kerajaan Kristen Katolik di Eropa yaitu Portugis ke kawasan laut dan kepulauan Maluku, termasuk di daratan Halmahera sejak abad ke-16 (1512) sudah ada di mana aktivitas keristenisasi mereka berlangsung hingga menjelang akhir abad ke-17. Informasi mengenai aktivitas kristenisasi di Loloda, ditandai oleh kehadiran seorang misionaris/pendeta Belanda yang bernama Van Baarda dan kemunculan beberapa pendeta lain hingga awal abad ke-20.

Pada 7 Oktober 1898 tatkala Van Baarda dalam perjalanan pulang ke Darume (Loloda Utara), terdengar berita bahwa masih tersisa dua orang Masehi (Kristen) yang belum dibebaskan dari penjara Soa-Sio, dengan adanya surat 
keterangan Sultan (Raja Ternate), kedua orang itu pun langsung dibebaskan, dan dalam perjalanannya ke Durume, Van Baarda sempat bertemu dengan perahu orang Pacao yang beragama Islam pergi mencari seorang pembunuh yang telah melarikan diri. Pemimpin rombongan perahu itu mengatakan kepada orangorang Kristen di Durume, bahwa sekembalinya mereka dari pencarian ini, mereka akan mampir ke Durume untuk berurusan dengan orang-orang Kristen di sana. Berita ini kemudian meresahkan hati orang-orang Kristen di Durume, tetapi tatkala van Baarda membacakan isi surat sri Sultan di hadapan mereka maka lenyaplah rasa takutnya dan menjadi tenang. ${ }^{28}$

Tanggal 8 Oktober 1898 Van Baarda menemui Raja Loda (Loloda) yang sementara berada di Dagasuli. Kepada raja Loda (Loloda) itu ditanyakan oleh Van Baarda, apakah sudah menerima surat dari Sri Sultan Ternate. Raja Loda (Loloda) menjawab Sri Sultan tetap berkeberatan atau tidak mengijinkan rakyatnya masuk agama Kristen, dan dikatakan bahwa orang Durume tidak lagi mengindahkan perintah rajanya maka sekarang telah tersedia balok pasungan kaki untuk memasung setiap orang yang sudah masuk agama Kristen supaya dijemur di matahari.

Mendengar penjelasan Raja Loda (Loloda) yang demikian, Van Baarda memperlihatkan surat Sri Sultan kepada raja tersebut disertai dengan penjelasan Van Baarda dan menarik kesimpulan bahwa hendaknya ia secepatnya menetap di kampung Durume agar dapat membendung ketakutan orang Kristen di situ untuk tidak melarikan diri ke kampung Pitu. Pada tanggal 13 Oktober

28 Magany, Bahtera Injil Halmahera. Tobelo: Gereja Injil Masehi Halmahera (GMIH) dan Arend L. Mapanawang,. 2012. Loloda Kerajaan Pertama Moluccas, h. 67.
1898, pada suatu tempat di kampung Durume diadakan pembakaran (pemusnahan) berhala. Di tempat itu kemudian dibangun gereja, mula-mula dibangun difak atau sabua semacam bangunan rumah tempat pertemuan dan pada tanggal 16 Oktober 1898 di tempat ini diselenggarakan pembaptisan sejumlah 70 orang. Dengan demikian sudah terdapat 130 orang Kristen di Loloda, yaitu 60 orang baptisan Tobelo dan 70 orang baptisan di Durume. Memang sudah sejak lama orang Durume tidak lagi menyelenggarakan gomanga (semacam upacara tolak bala) melainkan mereka mencari bantuan ke Tobelo bilamana terjadi sesuatu yang menimpa kampung. Setelah mengadakan persiapan seperlunya, Van Baarda menjemput istrinya yang masih berada di Duma dan tanggal 25 November 1898 bersama dengan dengan keluarganya telah berada kembali di Durume. Dari sebuah rumah kecil yang ditempatinya mereka melakukan kegiatannya baik terhadap orang-orang yang baru dibaptis maupun dengan mengadakan kontak dengan yang belum masuk agama Kristen. Baru saja beberapa hari mereka berada di Durume, terjadi pula suatu peristiwa, di mana saudara Raja Loda (Loloda) dari Dagasuli datang dan mengharukan orang-orang Kriten di Kampung Asimiro, sebuah kampung yang berdekatan dengan kampung Durume. Kepala kampung Asimiro yang baru saja dibabptis sebulan sebelumnya ditangkap dan dimasukkan ke dalam perahu untuk dibawa ke Kedi untuk dipenjarakan. Dikatakannya bahwa ia mendapat tugas dari raja Loda (Loloda) untuk mengusir pendeta dan mereka yang sudah dibaptis supaya kembali ke kepercayaan berhala sebelumnya. Tetapi tatkala melihat Van Baarda bersama keluarganya yang sudah berada di Durume di tengah orang 
Kristen, niat saudara Raja Loda (Loloda) itu dibatalkan lagi.

Penduduk dari kampung lain yaitu Asimiro, Salangade dan Jikolamo minta supaya mereka juga dibaptis. Dalam pada itu merekapun menyatakan keinginannya supaya mereka yang sudah dibabptis itu sebaiknya berkumpul saja di Durume membangun rumah berdampingan dengan rumah pendeta, mungkin karena takut kepada Raja Loda, atau ingin hidup dekat dengan pendeta supaya mudah menerima ajaran Kristen, namun pendeta van Baarda menganjurkan agar masing-masing mereka kembali saja ke kampung halamannya dan dari sana mereka membantu menyebarkan Injil.

Dengan adanya hasil kegiatan pembatisan di sana-sini maka mulailah lagi dilakukan pembakaran benda-benda berhala yang sebelumnya masih dianggap agama dan kepercayaan animisme dan dinamisme, yang percaya dengan roh-roh leluhur dan benda-benda keramat di lingkunan alam di mana mereka tinggal, untuk melayani orangorang Kristen yang baru di Asimiro. Di sini dibangun rumah guru agama Kristen, dan pembangunan rumah itu pun dibantu oleh Raja Loda, karena Raja Loda dianggap sudah tidak sanggup lagi membendung keinginan orang-orang di kampung itu untuk masuk agama Kristen, maka ditempuh jalan lain ialah memerintahkan supaya mereka yang sudah dibabtis itu berpindah ke Durume dan tinggal di dekat rumah pendeta yang ditugaskan Magany. ${ }^{29}$

Pada awalnya hal ini dimaksudkan untuk mewujudkan keinginan orangorang Kristen, namun sebaliknya justru timbul kekhawatiran bahwa di balik perintah itu ada maksud-maksud tersembunyi untuk mengusir mereka dari

\footnotetext{
29 Arend. L Mapanawang, Loloda Kerajaan Pertama Moluccas, h. 67.
}

kampung halamannya sendiri, dan ini berarti pula akan menghambat kristenisasi. Namun seperti yang dikatakan di atas, Hueting agar tiap-tiap orang kembali ke kampung halamannya maing-masing supaya dapat menyebarkan agama itu kepada orangorang yang belum menjadi orang Kristen. ${ }^{30}$

Perjalanan Raja Loda (Loloda) dalam menghambat pembangunan ruma guru agama Kristen di Asimiro baru dapat diredakan, tatkala Posthouder sendiri datang dari Galela dan menanam belo (patok) di tempat itu yang di atasnya bakan dibangun rumag guru agama Kristen. Dengan adanya belo yang ditangkap sendiri oleh Posthouder, Raja Loda menghentikan perlawanannya.

Setahun kemudian yakni pada tahun 1899, Residen dari Ternate mengunjungi Loloda dan sempat singgah di Durume, dalam kunjungan ini Residen sekali lagi mengingatkan Raja Loda agar tidak menghambat orang yang ingin memeluk agama Kristen. Pada pertengahan tahun 1899 Raja Loda mengunjungi kampung dengan maksud mengajak orang supaya jangan masuk agama Kristen, tetapi usaha Raja Loda tidak banyak hasilnya, di sana sini terdapat kegairahan warga masyarakat untuk memeluk agama Kristen.

$\begin{array}{lccc}\text { Ruma } & \text { guru agama } & \text { Kristen di } \\ \text { Asimiro } & \text { telah } & \text { siap } & \text { dibangun }\end{array}$
ditempatkan seorang guru di situ bernama Dores Nuha, seorang Penatua (tokoh adat kampung) dari Jamaah Duma yang diangkat menjadi guru Jemaah dan ditempatkan di Loloda untuk membantu Van Baarda. Dengan bantuan Dores Nuha sebagai guru tersebut, komunikasi antara pendeta

\footnotetext{
30 Magany, Bahtera Injil Halmahera, (Tobelo: Gereja Injil Masehi Halmahera (GMIH), 1984), dalam Arend L. Mapanawang, Loloda Kerajaan Pertama Moluccas, h. 69.
} 
dengan orang banyak makin bertambah pesat, hanya saja sangat disayangkan pada tahun 1900 Van Baarda terpaksa meninggalkan posnya di Durume dan harus pindah ke Galela (Duma) menggantikan Van Dijken yang telah meninggal dunia. Dari Duma, Van Baarda terus menjalankan visi misinya menyebarkan agama Kristen dan memimpin jamaahnya di Loloda, sedangkan Dores Nuha, tinggal bersamasama dengan jamaahnya di Loloda. Pekerjaan van Baarda semakin berat ketika ia harus merangkap tugas memimpin jamaah Kristiani baik di daerah pesisir pantai Loloda tetapi juga di daerah-daerah lereng pegunungan untuk seluruh Halmahera pada umumnya. Pekerjaan kristenisasi di Loloda diteruskan oleh Dores Nuha di mana ia kemudian dibangunkan sebuah gereja di Duruma tepat di atas tanah bekas tempat pembakaran berhalaberhala kepercayaan animisme dan dianisme penduduk sebelumnya, pekerjaan ini mendapatkan banyak rintangan. Pada tahun 1902, pengurus UZV mendatangkan Schut, yang dipindahkan dari Celebes (Sulawesi) ke Durume, mereka mengalami banyak kesulitan dalam hal perumahan, sebab pembangunan perumahan pendeta di Durume sangat lamban jalannya. ${ }^{31}$ Konferensi para pendeta tahun 1903 memutuskan agar Schut dipindahkan ke Kao, namun keputusan ini tidak dapat dilaksanakan karena ia dipertahankan oleh para anggota jemaah muda di Loloda ketika itu. Sikap para anggota jemaah muda dalam mempertahankan Schut tidak berlangsung lama kerena Schut kemudian terpaksa meninggalkan Durume untuk mendapatkan perawatan atas kesehatannya yang semakin

\footnotetext{
${ }^{31}$ Magany, Bahtera Injil Halmahera, (Tobelo: Gereja Injil Masehi Halmahera (GMIH), 1984), dalam Arend L. Mapanawang, Loloda Kerajaan Pertama Moluccas, h. 69.
}

menurun. Setelah dirawat ternyata Schut tidak kembali lagi ke Durume, melainkan dikirim ke tempat kerjanya yang baru di pulau Buru. Ketika bertugas di pulau Buru ia diangkat oleh Gubernemen Ambon untuk melaksanakan tugas sebagai Burgermeester di kota Ambon. Selama tugasnya itu ia juga sempat membantu pekerjaan UZV di Halmahera.

Ketika Van Baarda jatuh sakit ia selalu mengalami keterterlambatan dalam mendapatkan perawatan semestinya yang mengakibatkan kakinya pincang. Ia kemudian dikirim kembali ke Duma sebagai seorang yang timpang walaupun keadaan jasmaninya sudah tidak normal lagi, namun ia tetap melakukan kunjungan ke Loloda. Dalam kunjungannya ke Loloda ia mengalami banyak kekecewaan. Kepercayaan penduduk atas penganut Kristen di daerah ini mula-mula sangat berkobarkobar, namun akhirnya kini padam karena ketakutan terhadap raja Loda dan takut akan kemarahan Giki dan Gomanga (para petinggi adat setempat) sehubungan dengan aksi pembakaran benda-benda berhala penduduk setempat. Dalam pada itu dijumpainya pula Guru Dores Nuha yang sebelumnya sudah memipin jamaah, hidupnya tidak lagi menjadi teladan yang baik bagi jemaahnya, karena ia sudah menjadi pemabuk, maka guru itu pun dipecat dari jabatannya. Ia diganti dengan seorang guru agama yang baru, ia adalah anak angkat dari Pendeta Schut.

Pada masa itu juga di pulau Dagasuli dan Tuakara terdapat sejumlah orang Suku Sangir-Talaud, mereka adalah para pekerja dari suatu perusahaan kayu yang mengambil kayu hitam hasil hutan di daerah ini. Mereka mengajukan permintaan kepada Van Baarda agar diterima untuk menjadi anggota-anggota Jamaah Kristiani di Loloda. Hanya saja sangat disayangkan 
bahwa para pekerja dari suku SangirTalaud itu kebanyakan hidup sebagai pemabuk, sehingga dianggap tidak bisa memberi contoh yang baik kepada orang-orang yang dianggap kafir dan bukan Kristen, termasuk orang-orang Kristen yang ada di Loloda. Kebiasaan mabuk-mabukan ini sukar diberantas karena para pekerja itu dibayar gajinya oleh perusahaan tempatnya bekerja yang tidak peduli dengan kebiasaan buruk para pekerjanya itu.

Di pihak lain hambatan dari Raja Loda semakin meningkat sehingga pada beberapa tempat terjadi kasus-kasus pembunuhan. Peristiwa itu oleh Van Baarda dilaporkan kepada Residen Belanda di Ternate. Untuk mengamankan situasi itu didatangkan dan ditempatkan seorang kontrolir (pengawas) di Loloda. Seorang kontrolir biasanya adalah orang Belanda yang dilengkapi dengan sejumlah tentara (aparat militer) dan polisi bersenjata.

Van Baarda berpendapat bahwa sebaiknya untuk daerah Loloda ditempatkan seorang pendeta tetap, sehingga aktivitas kristenisasi tidak berhenti. Tenaga Van Baarda tidak dapat diharapkan terlalu banyak lagi karena sudah sering sakit-sakitan. Usul Van Baarda mendapat sambutan yang baik dari pengurus UZV di negeri Belanda, maka pada tahun 1906 pendeta baru didatangkan dari Irian (Papua) ke Halmahera yang bernama Metz.

Kedatangan Metz disertai oleh Van Essen ke Morotai, selanjutnya mereka berangkat ke kampung Bubo-Bubo. Kemudian Metz melanjutkan perjalanan ke Dorume dan kesulitan yang dihadapi masih berkisar pada masalah perumahan, rumah pendeta yang direncanakan belum juga siap. Namun kesulitan atas perumahan itu tidak mematahkan semangat para kaum misionaris itu untuk menyebarkan agama Kristen di Loloda. Setelah bertugas setahun hasil kerja pendeta itu sudah kelihatan yaitu bahwa dari 12 orang murid sekolah yang diajarkan agama Kristen, kemudian bertambah menjadi 34 orang. Ibadah Minggu yang sebelumnya biasanya hanya dihadiri rata-rata 60 orang, meningkat sampai 100 orang.

Pada tahun itu dampak positif yang lain juga muncul yaitu menurunnya aktivitas mabuk-mabukan yang sebelaumnya menjadi kebiasaan para warga setempat, jumlah kelahiran bayi meningkat dan usia harapan hidup juga bertambah. Sebelumnya jumlah kematian bayi setiap tahunnya sangat tinggi yang disebabkan oleh karena pengaruh negatif alkohol dari minumanminuman keras yang juga tidak asing bagi kaum wanita setempat, selain itu penanganan masalah rendahnya tingkat kebersihan lingkungan yang buruk (higienitas rendah).

Dalam menjalankan tugas, Metz dibantu oleh istrinya, namun masa tugasnya tidak terlalu lama di Loloda.Pada tahun 1913, mereka cuti ke Negerinya Belanda, dan sekembalinya dari cuti mereka ditugaskan di Tobelo. Pekerjaan Metz diteruskan oleh D.C. Prins. Pendeta D.C. Prins agaknya kurang menyetujui cara kerja orangorang dari UZV di Loloda, ia beralih ke Celebes (Sulawesi), ia kemudian masuk bergabung ke organisasi GZB di Tanah Toraja. Van Baarda yang sudah lanjut usia itu menjalankan tugas rangkap di Loloda sampai akhirnya pensiun di tahun 1917. Dengan pensiunnya Van Baarda, usaha kristenisasi di Loloda kembali lagi dipimpin oleh Metz. Loloda hanya mendapat kunjungan secara insidental saja, karena padatnya tugas yang harus dilaksanakannya di Tobelo.

Nampaknya cara jarak jauh dalam menjalankan tugas tidak banyak bisa diharapkan hasilnya dan keadaan demikian berlangsung terus sampai dengan tahun 1921 ketika pendeta Boger 
mulai bertugas di Galela (Duma), tugas kristenisasi di galela dan Loloda dirangkap oleh pendeta tersebut. Boger lebih banyak menggunakan waktunya di Loloda dan Galela karena kedua daerah itu berdekatan jaraknya dan mudah untuk didatangi dibandingkan dengan Tobelo. Ketika Boger menjalani cuti, tugas berkunjung ke Loloda diserahkan kepada Rooseboom yang pada saat itu bertugas di Galela. Pada waktu Rooseboom berpindah ke Tobelo, ia masih sempat mengunjungi Loloda sekali lagi. Demikianlah sampai pecahnya Perang Dunia II, ketika bala tentara pendudukan Jepang berkuasa di Halmahera, Loloda hanya dikunjungi oleh pendeta-pendeta dari Galela dan Tobelo. ${ }^{32}$

Menurut para misionaris, usaha misi kristenisasi di Loloda ketika itu, nampaknya banyak mengalami kendala, menurut mereka tantangan dan hambatan itu terutama berasal dari luar yaitu dari kalangan Islam. Berbeda dengan apa yang terjadi di Galela dan Tobelo, di Loloda keuletan para misionaris dalam menjalankan misi kristenisasinya senantiasa dituntut. Di Galela dan Tobelo kemunculan tunastunas muda misi kristenisasi nampak lemah dan lamban, sehingga dituntut kesabaran dari para misionaris yang bertugas di dua daerah itu. Jika tidak, maka rasa putus asa mereka akan selalu muncul. Para misionaris misi kristenisasi lokal maupun asing di Loloda mengharapkan agar tunas-tunas muda misi kristenisasi sudah seharusnya tumbuh terlebih dahulu sebelum para misionaris datang ke daerah ini. Menurut mereka bertugas di Loloda diperlukan modal keberanian lebih penting daripada kesabaran. Tidak demikian halnya di

\footnotetext{
32 Magany, Bahtera Injil Halmahera. (Tobelo: Gereja Injil Masehi Halmahera (GMIH), 1984), dan Arend L. Mapanawang, Loloda Kerajaan Pertama Moluccas, h. 72.
}

Galela dan Tobelo, di kedua daerah ini aktivitas para misionaris zending sepi, sedangkan di Loloda orang-orang yang sudah dibaptis selalu ingin tinggal berdampingan dengan para pendeta yang bertugas, mereka ingin tinggal sepekarangan dengan para pendetapendeta mereka.

Faktor pendorong sehingga orangorang baptisan itu ingin tinggal secara demikian dengan para pendetanya, ialah diakibatkan karena adanya rasa takut atas tekanan-tekanan dari Raja Loda selain keinginan untuk lebih muda mendapatkan bimbingan rohani dari para pendeta yang bersangkutan.

Pada era tahun 1846, seorang misionaris berkebangsaan Jerman yang mendapat ijin dari Sultan Ternate, bahkan diberi fasilitas berupa perahu kora-kora lengkap dengan pendayungnya untuk digunakan dalam perjalanan dari Ternate ke Loloda kepulauan untuk menyebarkan agama Kristen Protestan. Para jamaah yang tinggal di Pulau Doi mengenal pendeta itu dengan nama Puga. Pada awalnya pendeta itu memsuki desa Gogutingan, kemudian ke Dedeta dan Dagasuli namun oleh masyarakat di dua desa itu menolak kedatangan Pendeta Puga dengan serangan anak panah. Setelah tiba di Dowonggila dan Cera, sebelum mereka berbalik pulang, pendeta itu mengangkat tangan dan berdoa serta mengatakan biarlah waktu yang berbicara untuk mereka yang menolak ajakan Tuhan serta yang menyambutnya dengan anak panah.

\section{Penutup}

$\begin{array}{llr}\text { Loloda sebagaimana } & \text { halnya } \\ \text { kerajaan-kerajaan lainnya } & \text { yang } \\ \text { sebelumnya hanya dianggap } & \text { kecil } \\ \text { dengan peranan yang lemah dan tidak } \\ \text { signifikan dalam percaturan politik lokal } \\ \text { maupun regional yang pernah sekian }\end{array}$


lama eksis di kawasan laut dan kepulauan Maluku, selayaknya dapat dianalisa dan diteliti, serta ditulis kembali sebagai salah satu mata rantai sejarah yang terputus dan hilang). Loloda adalah sebuah kata, nama, dan kosep yang baik secara etimologi maupun terminologi adalah identik dengan suatu bahasa, etnik, budaya (adat kebiasaan dan tradisi), wilayah (geografis), kerajaan, mitologi, maupun sejarah. Loloda dapat dikatakan sebagai salah satu daerah di Maluku Utara dalam sejarah yang menjadi objek persaingan dalam agamisasi antara para ulama/mubaligh yang menyebarkan Islam (Islamisasi), melawan para pendeta/misionaris/orientalis dari EropaBarat (Portugis, Spanyol, Belanda), bahkan Jerman yang datang ke kawasan ini sebagai penyebar agama Kristen Katolik dan Protestan.

Masuk dan berkembangnya agama Islam dan Kristen di Loloda tidak terlepas dari kehadiran para pedagang Islam dari Timur Tengah (Arab) dan India (Gujarat), bahkan Cina, dan kehadiran para pendeta/misionaris yang ikut serta dalam penjelajahan dan penemuan daerah-daerah baru di luar dunia Eropa sambil membawa visi-misi 3G (gold, glory, dan gospel =kekayaan, agama, dan kehormatan) yang kemudian telah dianggap menjadi kaum penjajajah (kolonialis/imperialis) hingga beberapa ratus tahun lamanya. Baik di Asia, Afrika, Amerika Latin, maupun di wilayah-wilayah lainnya di kawasan Asia Pasifik dan Australia, seperti Oseania (Mikronesia, Polinesia, Fiji, dan Salomon).

Struktur tradisional organisasi politik pemerintahan Kerajaan Loloda sudah sejak lama menggunakan ajaran agama Islam sebagai landasannya. Terutama sejak abad ke-17.Kerajaan Loloda menjadikan Islam sebagai agama resmi yang dianut oleh para raja dan bangsawannya berikut para pejabatnya. Namun meskipun demikian, rupanya Islam belum mengakar di masyarakat Loloda terutama yang tinggal di daerahdaerah pedalaman dan pegunungan, karena ternyata sebagian besar penduduk kerajaan Loloda bahkan hingga sekarang, nampaknya masih didominasi oleh warga Kristen di banyak kampung dan desa-desa di sana. Ini berarti bahwa prinsip "top down" (syiar Islam dari pihak raja dan istana Loloda tidak menurun secara signifikan kepada masyarakat dan penduduk) setempat. Hasil-hasil kerja syiar (dakwah) Islam di Loloda tidak begitu mengakar pada warga masyarakat di seluruh wilayah kerajaan ini, baik yang tinggal di pedalaman, pegunungan, pesisir, maupun di kepulauan. Dengan demikian hingga kini secara umum Loloda sangat sulit untuk dikenali sebagai kerajaan Islam atau kesultanan, meskipun Sultan Ternate, Mudaffar Sjah (almarhum) yang meninggal Februari 2015 lalu pernah menyebut-nyebut bahwa Loloda juga adalah Kesultanan di Maluku Utara.

Nampaknya toleransi beragama, berkeyakinan, dan berkepercayaan, yang dipegang teguh oleh para raja dan bangsawan Loloda yang sudah memeluk Islam, bahwa "tidak ada paksaan kepada orang lain yang bukan Islam untuk memeluk agama Islam" dan "andaikan Raja Loloda menyuruh agar seluruh warga masyarakat Loloda wajib masuk Islam tanpa kecuali, maka semua warga masyarakat Loloda kapan dan di manapun pasti akan memeluk agama Islam dan menjadi penduduk Muslim", dan prinsip ini nampaknya melekat dengan begitu kuatnya. Tetapi, meskipun demikian para raja yang sebelumnya pernah berkuasa di Loloda sesungguhnya sudah pernah pula melakukan upaya-upaya sedemikan rupa untuk meningkatkan program Islamisasi di sana, di samping mencoba 
membendung semakin merajalelanya aktivitas Kristenisasi yang sudah dianggap berbahaya dan meresahkan, yang dijalankan oleh para misionaris Eropa itu, terutama Belanda dari abad ke-17 hingga menjelang akhir abad ke20, dengan mengerahkan segala fasilitas, sarana-prasarana, juga semua suprastruktur dan infrastruktur yang mereka miliki, namun nampaknya upaya raja Loloda tidak memberikan hasil yang berarti bahkan gagal. Seolah sikap toleransi raja-raja Loloda kepada rakyatnya yang begitu sangat bijak itu dengan prinsip "tidak ada paksaan orang-orang yang belum memeluk Islam untuk memeluk Islam”, yang kemungkinan tanpa sadar sikap yang begitu lunak dan toleran itu, justru dimanfaatkan oleh para misionaris untuk menggencarkan pelaksanaan visi misi Kristenisasinya di sana-sini di Loloda, baik ajaran Kristen Roma Katolik maupun Kristen Protestan, dengan sasaran adalah kepada para warga masyarakat kawula kerajaan yang jauh dari istana sebagai pusat kontrol kekuasaan dan jauh dari jangkauan perhatian para penguasa Loloda ketika itu. Sasaran visi-misi Kristenisasi terutama ditujukan kepada suku-suku bangsa "Alifuru" (suku-suku bangsa yang terhitung masih primitif yang banyak dijumpai terutama di daerah pedalaman, hutan, dan pegunungan), yang jumlahnya masih sangat banyak.

Ada suatu taktik dan strategi yang dilakukan oleh para misionaris Eropa baik itu Portugis, Spanyol, tetapi terutama nampak pada orang-orang Belanda, dalam menjalankan visi misi Kristenisasinya, ialah dengan selalu membawa-bawa nama penguasa tertinggi di Ternate, baik itu raja ataupun Sultan. Ketika mereka merasa terdesak oleh Raja-raja dan bangsawan Loloda yang sudah beragama Islam untuk tidak lebih menggencarkan lagi program visi dan misi Kristenisasinya di dunia Maluku bagian utara termasuk Loloda, ialah dengan selalu menyebut dan mengatakan bahwa mereka telah mendapatkan izin dari Raja atau Sultan Ternate, di mana kerajaan ini adalah yang terkuat, sebagai kerajaan penguasa Maluku di antara tiga kerajaan Moloku Kie Raha lainnya (Tidore, Bacan, dan Jailolo).

Perlu diketahui bahwa pada periode antara abad ke-17 dan ke-19, pengaruh kekuasaan Kesultanan Ternate telah meluas ke kawasan Halmahera Utara dan Barat, dan menundukkan kerajaan-kerajaan lain yang ada di daratan dan kepulauan Halmahera lainnya, termasuk Loloda. Sikap menghormat raja-raja dan bangsawan Loloda umumnya sangat tinggi kepada para penguasa di Kerajaan/Kesultanan Ternate, setidaknya dalam situasi dan kondisi tertentu. Selain itu para pendeta/misionaris Belanda misalnya dalam menjalankan program kerja Kristenisasinya (Protestan) selalu membawa "surat pengantar" dan "surat izin" yang diakuinya berasal dari dan ditandatangani oleh Sultan Ternate, sebagai bukti bahwa mereka sebagai pendeta/misionaris diperbolehkan menjalankan usahanya tersebut, meskipun harus dianalisa lebih jauh bahwa ini ada kemungkinan ini hanyalah sebuah "modus operandi" (taktik/strategi) dari para misionaris sebagai "Pekabar Injill" agar kegiatannya di Loloda misalnya, tidak dihalanghalangi oleh pihak kerajaan terutama Raja Loloda, yang berada di bawah kekuasaan Raja Ternate.

Ketika para misionaris Belanda dan orang Eropa lainnya merasa terdesak dan terhalang kegiatan Kristenisasinya termasuk kristenisasi orang-orang Loloda, mereka menyampaikan katakata yang sifatnya diplomatis, sambil memperlihatkan semacam "surat izin" 
yang diakuinya berasal dari Sultan Ternate yang isinya bahwa mereka diperbolehkan oleh Sultan untuk menjalankan program Kristenisasinya tanpa halangan apapun, tanpa pernah disadari apakah "surat izin" itu asli atau palsu. Hal ini disebabkan karena para misionaris menganggap bahwa tidak selamanya para raja dan kerajaankerajaan yang berada di bawah kekuasaan Ternate di Halmahera dan sekitarnya seperti Loloda pada periode itu dengan begitu mudahnya dapat berhubungan langsung dengan raja pusat di Ternate, karena fasilitas (sarana dan prasarana) untuk melakukan itu sangat terbatas dan sulit. Yang bisa melakukannya dengan mudah hanyalah para kaum misionaris Eropa yang memang sejak dari asalnya sudah diberikan bekal berupa fasilitas memadai dan modern untuk menjalankan visi-misi Kristenisasinya baik Katolik maupun Protestan. Selain itu, pihak Kesultanan Ternate juga tidak terlepas dari pemanfaatan fasilitas seperti itu namun tetap dengan kontrol dan batasanbatasan tertentu dari pihak kolonial.

Dapat diduga pula bahwa pihak misionaris pada masa itu melakukan berbagai cara untuk mensukseskan maksud dan tujuannya termasuk dengan bohong/dusta dengan "menjual" dan "membawa-bawa nama penguasa berpengaruh di tingkat pusat", di samping penggunaan taktik dan strategi "adu domba" (devide et impera), antara Sultan Ternate dengan Raja Loloda beserta rakyatnya yang menolak Kristenisasi di Halmahera dan sekitarnya.

Sikap raja-raja Loloda yang begitu bijaksana dalam prinsip Islamisasinya terhadap penduduk di wilayah kerajaannya, bahwa "tidak ada paksaan dalam memeluk Islam"adalah suatu sikap toleransi yang sangat luar biasa sejak dahulu. Tetapi pada satu sisi sikap bijaksana raja Loloda yang seperti ini membwa resiko dan konsekuensi lain, yaitu bahwa kebijakan itu justru dimanfaatkan oleh para kaum misionaris Kristen untuk semakin menggencarkan kegiatan kristenisasinya di negeri Loloda, yang berarti bahwa penduduk Loloda yang beragama Islam dan menjadi muslim justru berada pada posisi minoritas, sedangkan penduduk Kristen berada dalam posisi yang mayoritas.

Inilah yang menjadi faktor penyebab mengapa Islamisasi yang dijalankan oleh pihak Kerajaan Loloda tidak begitu mengakar di kalangan komunitas masyarakatnya di tingkat bawah terutama pada suku-suku bangsa Alifuru yang banyak tinggal di daerahdaerah pedalaman dan pegunungan di daratan Halmahera. Sehingga dengan demikian penduduk Islam di Halmahera tidak justru menjadi mayoritas untuk semua kampung pemukiman penduduk di wilayah Kerajaan Loloda, baik yang ada di Halmahera Utara maupun Halmahera Barat, bahkan hingga sekarang ini perbandingannya bisa dikatakan 40:60 (Islam 40 persen dan Kristen 60 persen). Indikatornya dapat dilihat pada perbandingan jumlah rumah ibadah antara Mesjid (termasuk surau, langgar, mushallah) dengan gereja. Namun demikian, suatu hal yang sangat luar biasa yang bisa dijumpai dalam kehidupan sosial masyarakat di Loloda bahkan hingga kini, ialah bahwa tolerasi yang terjadi di antarkelompok masyakat penganut dua agama ini nampaknya masih sangat tinggi, di mana konflik sosial massal horizontal yang membawa alasan agama memang sulit ditemukan. Yang lebih unik lagi ialah bahwa dukungan atas upaya pemulihan kembali eksistensi kerajaan Loloda sebagai salah satu dari lima kerajaan utama di dunia Maluku yang hilang selama ini untuk dibangkitkan kembali, justru sangat kuat 
dari kalangan penduduk beragama Kristen. Terlepas dari tendensi-tendensi

\section{Daftar Pustaka}

Abdulrahman, H.M. Jusuf. 2002. Kesultanan Ternate dalam "Jou Ngon Ka Dada Madopo Fangare Ngom Ka Alam Madiki" (Moti Verbond 1322). Menado: Media Pustaka.

Abdurrachman, Paramita R, R.Z. Leirissa, dan C.P.F. Luhulima, dkk. 1973. Bunga Rampai Sejarah Maluku I. Jakarta: Lembaga Penelitian Sejarah Maluku.

Abdurrachman, Paramita R. 2008. Bunga Angin Portugis di Nusantara: Jejak-Jejak Kebudayaan Portugis di Indonesia. Jakarta: LIPI PressAsosiasi Persahabatan dan Kerja sama Indonesia-Portugal dan Yayasan Obor Indonesia.

Amal, M. Adnan. 2010. Kepulauan Rempah-Rempah: Maluku Utara Perjalanan Sejarah 1250-

1950. Jakarta: Kepustakaan Populer Gramedia (KPG).

Andaya, Leonard. 1993. The world of Maluku. Honolulu: University of Hawaii.

Assegaf, U.M. 1974. "Sedikit tentang Maluku Utara”. Buletin IKMU Surabaya. Medio Januari.

Baarda, M.J. van. 1904. "Het Loda'sch, in vergelijking met het Galela'sch dialect op Halmaheira". BKI. Vol. 56, No. 1, 1904. Diakses dari lain dalam kehidupan sosial keberagamaan di Loloda.

http://www.kitlvjournals.nl/index .php/btlv/article/viewFile/6762/7 529,pada 20 November 2012, pkl. 19.48 WIB.

Baretta, J.M. 1917. Halmahera en Morotai Bewerk Naar de Memorie van Den Kapitein van Den Generalen Staf. Batavia: Javasche Boekhandel \& Drukkerij.

Brumund, J.F.G. 1856. Fragment Mijner Reize door de Molukko's Makjan en Batjan. Batavia: Lange.

Busranto Abdul Latif Do'a. 2005. "Sistem Kemasyarakatan Tradisional Ternate dalam Perspektif Budaya Modern" dalam Mudaffar Sjah, et. al., Moloku Kie Raha dalam Perspektif Budaya dan Sejarah Masuknya Islam. Ternate: HPMT Press.

Coolhaas, W. Ph. 1923. "Kroniek van het Rijk Batjan", Overgedrukt uit Het Tijdschrijft van Het Koning Batjan. Genootschap van Kunsten en Wetenschap, deel LXIII, afl.2.

Coolhaas, W. Ph. 1926. Meedelingen Betreffende de Onderafdeeling Batjan. 's Gravenhage: Nijhoff.

Crab, P. Van der. 1862. De Moluksche Eilanden: Reis van Z.E den Gouverneur-Generaal Charles Ferdinand Pehud door den Molukschen Archipel. Batavia: Lange en Co. 
De Clerq, F.S.A. 1890. De Bijdragen tot de Kennis der Residentie Ternate. Leiden: Brill.

Djafaar, Irza Arnyta. 2007. Jejak Portogis di Maluku Utara. Jakarta: Ombak

E.W. Parengkuan, Fendy. 1982/1983. Pengaruh Penyebaran Agama Islam terhadap Kehidupan Sosial Politik di Daerah Sulawesi Utara, kumpulan tulisan dalam Departemen P \& K. 1982/1983.Seminar Sejarah Nasional III: Seksi Pasca Kuno. Jakarta: Departemen P \& KDirektorat Sejarah dan Nilai Tradisional-Proyek Inventarisasi dan Dokumentasi Sejarah Nasional, hlm. 216-247.

Fraassen, Chr. F. Van.1985. Ternate, de Molukken en de Indonesische Archipel: van Soa Organisatie en Vier Deling-Een Studie van Traditionale Samenleving en en culture Indonesie, 1 Vol. Leiden: Leiden Universiteit.

Molukken en de Indonesische Archipel: van Soa Organisatie en Vier Deling-Een Studie van Traditionale Samenleving en en culture in Indonesie, 2 Vols. Leiden: Leiden Universiteit.

Giddens, Anthony. 1984. The Constitution Of Society: Outline of The Theory Of Structuration. California USA: University of California Press.
Goldman, C.F. 1858. Toght door Eenige Gedeelten van Residentie Ternate. Batavia.

Gruneman, I. 1907. In de Molukken Reis met de Booten der "Koningklijke Paketvaart-Maatschappij".

Amsterdam: Holkema \& Warendorf.

Haire, J. 1979. The Character and Theological Struggle of The Church in Halmahera-Indonesia, 1941-1979. Frankfurd: Verslag Peter Delang Ammain.

Hasan, Abdul Hamid. 2001. Aroma Sejarah dan Budaya Ternate. Jakarta: Antara Pustaka Utama.

Jacobs, Hubert Th.Th. M. 1971. "A Treatise on The Moluccas (c.1544): Probably Preliminary Version of Antonio Galvao's Lost", Historia Das Moluccas, Edited, Annotated, and Translated in to English from The Portuguese Manuscript in The Archivo General de Indies, Seville. Rome, Italy: Jesuit Historical Institute via dei Penitenzieri 20 00193, St. Louis University, St Louis, Mo. 63103, USA.

Jafar, Nani, dkk. 2007. Profil Sejarah dan Budaya Halmahera Barat (hasil penelitian). Ternate:

Fakultas Sastra dan BudayaUnkhair.

Jagt, M.B. Van der. 1935. Molukken Reis, 10 september-30 Nopember 1923. Den Haag.

Jones, P.I.P. 2009. Pengantar TeoriTeori Sosial: dari Teori Fungsionalisme hingga 
Pomodernisme (Terjemahan Achmad Fediyani Saifuddin). Jakarta: Yayasan Obor Indonesia.

Juynboll, H.H. 1930-1932. Molukken. Leiden: Brill: Catalogus van 's Rijks Ethnographisch Musem.

Katoppo. 1984. Nuku, Perjuangan Kemerdekaan di Maluku Utara. Jakarta: Sinar Harapan.

Kern, H. 1890. Chritisch Overzicht, van "Bijdragen tot de Kennis der Reis Ternate, ddor F.S.A. de Clerq. Amsterdam: Brill.

Kenley, David L. 2003. New Culture in A New World: The May Fourth Movement and The Chinese Diaspora in Singapore, 19191932. New York \& London: Routledge..

Klerk, J.E. de. 1864. Batjan. Batavia: Lange.

Lapian, B. Adrian. 2009. Orang Laut, Bajak Laut, Raja Laut: Sejarah Kawasan Laut Abad XIX. Pustaka Hikmah Disertasi (Ph.D) Seri III. Depok: Komunitas Bambu.

Leirissa, R.Z. 1990. Masyarakat Halmahera dan Raja Jailolo: Studi tentang Sejarah Masyarakat Maluku Utara. Disertasi. Jakarta: Fakultas Pascasarjana-Universitas Indonesia.

Leirissa, R.Z. 1996. Halmahera Timur dan Raja Jailolo: Pergolakan Sekitar Laut Seram Awal Abad Ke-19. Jakarta: Balai Pustaka.
Leirissa, R.Z. 2001. "Jalur Sutera: Integrasi Laut-Darat dan Ternate sebagai Bandar di Jalur Sutera" dalam Yusuf Abdulrahman, et al., Ternate Bandar Jalur Sutera. Ternate: Lintas.

Lewis, Bernard. 2009. Sejarah: Diingat, Ditemukan Kembali, DitemuCiptakan. Yogyakarta: Ombak.

Lubis, Akhyar Yusuf. 2014. Postmodernisme, Teori dan Penerapannya. Jakarta: PT. RadjaGrafindo Persada.

Magany. 1984. Bahtera Injil Halmahera. Tobelo: Gereja Injil Masehi Halmahera (GMIH).

Mansyur, Mustafa 2007. Loloda dan Integritas Kesultanan Ternate (1945-1999). Ternate: Program Studi Ilmu Sejarah-Fakultas Sastra dan Budaya-Universitas Khairun (Skripsi).

Mansyur, Mustafa. 2013. Transformasi Politik di Loloda Maluku Utara (1808-1945). Bandung: PPSUNPAD (Tesis).

Mapanawang, Arend. L. 2012. Loloda Kerajaan Pertama Moluccas (Sejarah Kerajaan Loloda Maluku). Tobelo: Yayasan Medika Mandiri Halmahera.

Marasabessy, Abd. Rahman, dkk. 2012. Sejarah Sosial Kesultanan Ternate. Ombak.

Masinambow, E.K.M. (ed.). 1980. Halmahera dan Raja Ampat Konsep dan Strategi Penelitian. Jakarta: Lembaga Ekonomi dan 
Kemasyarakatan (LeknasLIPI).

Nasional

Migdal, Joel S. (ed.). 2004. Boundaries and Belonging: States and Societies in the Stuggle to Shape Identities and Local Practices. Cambridge: Cambridge University Press.

Muhammad, Syahril. 2004. Kesultanan Ternate Sejarah Sosial Ekonomi \& Politik. Yokyakarta: Ombak.

Olivier, Jz., J. 1824. Reizen in den Molukschen Archipel naar Makassar enz.: in het Gevolg van den Gouverneur-Generaalvan Nederland's Indie in 1824 Gedaan: Amsterdam: Beijenrinch, 1834-1837.

Pradjoko, Didik dan Friska Indah Kartika. 2014. Pelayaran dan Perdagangan Kawasan Laut Sawu. Jakarta: Wedatama Widyasastra.

Pires, Tome. 2014. Suma Oriental, Armando Cortessao: Perjalanan dari Laut Merah hingga ke Cina dan Buku Francisco Rodrigues (terjemahan oleh: Adrian Perkasa dan Anggita Pramesti dengan kata pengantar oleh: Sri Margana). Yogyakarta: Ombak

Putuhena, Saleh. 1983. "Struktur Pemerintahan Kesultanan Ternate dan Agama Islam". dalam E.K.M.Masinambow, Halmahera dan Raja Ampat. Jakarta: Leknas LIPI.

Qudsy, Saifuddin Zuhri (ed.). 2010. Anthony Giddens: Teori Strukturasi (Dasar-Dasar Pembentukan Struktur Sosial
Masyarakat. Yogyakarta: Pustaka Pelajar.

Rahman, Abdul. 2009. Pengembangan Geografi dan Nilai Sejarah Persekutuan Moti (Motir Verbond) 1322 M (Laporan Hasil Penelitian). Ternate: Fakultas Sastra dan BudayaUniversitas Khairun Ternate dan Dinas Kebudayaan dan Pariwisata Kota Ternate.

Resink, G.J. 2013. Bukan 350 Tahun Dijajah (Kata Pengantar: A.B. Lapian). Depok: Komunitas Bambu.

Sahlins, Marshall D. 1987. Islands of History. London: Tavistock Publication, Ltd. \& Chicago: Chicago University-USA.

Sahlins, Marshall D. 1987. Historical Metaphors and Mythical Realities. Michigan: Michigan University-USA.

Sigarlaki, A., dkk. 1977/1978.Sejarah Daerah Sulawesi Utara. Jakarta: Depdikbud-Puslit Sejarah \& Budaya-Proyek Penelitian dan Pencatatan Kebudayaan Daerah Departemen P \& K.

Suminar, dkk. 2003. Integrasi dan Disintegrasi dalam Perspektif. Jakarta: Badan Pengembangan dan PariwisataDeputi Bidang Pelestarian dan Pengembangan BudayaDirektorat Tradisi dan Kepercayaan-Proyek Pelestarian dan Pengembangan Tradisi dan Kepercayaan.

Supit, Bert. 1986. Minahasa: Dari Amanat Watu Pinawetengan 
sampaiGelora Minawanua.

Jakarta: PT. Sinar Harapan.

Suryo, Djoko. 2005. "Bulan Sabit di Bawah Rimbunan Cengkeh; Islamisasi Ternate atau Ternatesasi Islam" dalam Moloku Kie Raha dalam Perspektif Budaya dan Sejarah Masuknya Islam. Ternate: HPMT Press.

M. Sjah, Hidayatullah. 2005. "Sultan Jailolo:

Melengkapi Kesempurnaan Moloku Kie Raha" dalam Mudaffar Sjah, et al., Moloku Kie Raha dalam Perspektif Budaya dan Sejarah Masuknya Islam. Ternate: HPMT Press

Sjah, Mudaffar, et al. 2005. Moloku Kie Raha dalam Perspektif Budaya dan Sejarah Masuknya Islam. Ternate: HPMT Press.

Vansina, Jan. 2014. Tradisi Lisan sebagai Sejarah (penerjemah: Astrid Reza,dkk). Yogyakarta: Ombak.

Visser, Leontine E (ed.). 1980. Halmahera and Beyond: Social Science Research in The Moluccas. Leiden: KITLV Press.

Yusuf, Talabudin. 2005. "Sejarah Kesultanan Ternate" dalam Mudaffar Sjah, et al., Moloku Kie Raha dalam Perspektif Budaya dan Sejarah Masuknya Islam. Ternate. HPMT Press, hlm. 45.

Zuhdi, Susanto. 2010. Labu Rope Labu Wana: Sejarah Buton yang Terabaikan. Jakarta: RadjaGrafindo Persada. 